\title{
PELA BOLA: MODAL SOSIAL PELA YANG DIBENTUK MELALUI SEPAKBOLA SEBAGAI KEKUATAN DALAM HUBUNGAN ISLAM-KRISTEN DI MALUKU
}

\author{
Sofia Liana Adriaansz ${ }^{1}$, Izak Yohan Matriks Lattu ${ }^{2}$, Rama Tulus Pilakoannu ${ }^{3}$ \\ Magister Sosiologi Agama, Fakultas Teologi, Universitas Kristen Satya Wacana, Salatiga, \\ Indonesia ${ }^{123}$ \\ sofialiana06@gmail.com ${ }^{1 *}$
}

\begin{abstract}
This article aims to analyze the creation of Pela relationships formed through football media as an arena for the integration of Christian Islamic relations that are built in cultural identity-based kinship relations, Pela Bola. This study focuses on the relationship of Pela Bola in Mamala and Lateri, Maluku. In this study the author uses the theory of social capital by Francis Fukuyama and several other social capital ideas from Robert Putnam and is also supported by several other theories. The method used is qualitative research with in-depth interview techniques, observation, documentary studies and literature studies. The results of the study found that the creation of local identities, namely the Pela kinship in Mamala and Lateri, could occur through a medium, namely football. Pela Bola is a very strong social capital to integrate the community and maintain the solidarity of interfaith relations which is manifested through football media as an arena of integration in creating cultural identity based on local wisdom in strengthening kinship in the Islamic-Christian community in Maluku.
\end{abstract}

Keywords: Football; Lateri; Mamala; Mollucan; Pela; Social Capital;

\begin{abstract}
Abstrak
Artikel ini bertujuan untuk menganalisis terciptanya hubungan Pela yang terbentuk melalui media sepakbola sebagai arena integrasi hubungan Islam Kristen yang dibangun dalam hubungan kekerabatan berbasis identitas kultural yakni Pela Bola. Penelitian ini berfokus pada hubungan Pela Bola di Negeri Mamala dan Lateri, Maluku. Dalam penelitian ini penulis memakai teori modal sosial oleh Francis Fukuyama dan beberapa pemikiran modal sosial lainnya dari Robert Putnam serta didukung juga oleh beberapa teori lainnya. Metode yang digunakan ialah penelitian kualitatif dengan teknik wawancara mendalam, observasi, studi-studi dokumenter dan studi pustaka. Hasil penelitian menemukan bahwa penciptaan identitas lokal yakni hubungan kekerabatan Pela di Negeri Mamala dan Lateri dapat terjadi melalui sebuah media yaitu sepakbola. Pela Bola menjadi sebuah modal sosial yang sangat kuat untuk mengintegrasikan masyarakat dan mempertahankan solidaritas hubungan antaragama yang diwujudkan melalui media sepakbola sebagai arena integrasi dalam menciptakan identitas kultural berasas kearifan lokal dalam mempererat hubungan kekerabatan dalam komunitas Islam-Kristen di Maluku.
\end{abstract}

Kata Kunci: Lateri; Maluku; Mamala; Modal Sosial; Pela; Sepakbola.

\section{Pendahuluan}

Artikel ini akan mengkaji tentang hubungan pela sebagai sebuah nilai kearifan lokal masyarakat Maluku yang dibentuk dari sebuah media budaya pop yang tengah mendunia yakni sepakbola. Faktanya, sepakbola menjadi sebuah media dalam menciptakan arena integrasi sosial berbasis identitas kultural dalam hubungan Salam-Sarani (Islam-Kristen) di Maluku khususnya negeri 
(Komunitas masyarakat adat) Mamala Amalatu dan Lateri. Pela sebagai sebuah kearifan lokal yang telah turun-temurun menjadi warisan leluhur dalam menjaga keharmonisan dan stabilitas persaudaraan orang Maluku. Pela merupakan suatu relasi perjanjian dengan satu atau lebih negeri lain yang sering berada di pulau lain dan kadang juga menganut agama lain. Bisa dikatakan pela merupakan suatu tradisi dan tatanan kultural yang telah mampu membentuk persepsi, sikap, keyakinan, perilaku dan tindakan-tindakan masyarakat pendukungnya.

Di Maluku dikenal dengan istilah Pela-Gandong yang merupakan tradisi saling menghargai antar pemeluk agama antara satu desa dengan desa yang lain yang terbina dari asal-muasal. Baik itu dari hubungan kekerabatan genealogis, atau hubungan kekerabatan karena perjanjian saling membantu nenek moyangnya zaman dulu (Bartels, 2017). Penelitian tentang tradisi hubungan pela ini sendiri telah banyak dilakukan oleh para penulis sebelumnya. Para penulis terdahulu lebih jauh mengkaji tentang bentuk-bentuk tradisi pela antara lain pela darah, pela batu karang, pela tampa sirih, (Lattu, 2014; Huwae, 1995; Wattimena, 2010). Selain itu juga beberapa penulis mengkaji tentang tradisi pela sebagai sarana rekonsiliasi terhadap konflik agama di Maluku (Iwamony, 2010; Atammimy, 2014). Berbeda dengan penelitianpenelitian sebelumnya penelitian ini bertujuan untuk menggali tradisi hubungan pela yang diikat atau dibentuk melalui media sepak bola. Selain itu, terdapat beragam studi tentang sepakbola dan relasi sosial (Kupper, 1994; Lattu, 2018; Handoko, 2008), tetapi dirasakan penulis sangat kurang sebaliknya studi seputar sepakbola hanya dalam bingkai rivalitas, konflik dan kekerasan yang mengakibatkan timbulnya disintegrasi (Giulianotti, 1995; Sukmono, 2015; Prastyawan, 2018; Rumpoko, 2018) tetapi penulis belum menemukan tulisan terkait dengan hubungan kekerabatan berbasis identitas kultural yang diikat melalui permainan sepak bola sebagai media pemersatu sehingga menciptakan integrasi antar umat beragama.

Tulisan ini akan mengkaji tentang hubungan kekerabatan pela bola di negeri Mamala dan Lateri dengan melihat tradisi hubungan pela sebagai sebuah modal sosial masyarakat Maluku yang diciptakan dan diikat oleh sebuah media yakni sepakbola sebagai arena integrasi sosial berbasis identitas kultural dalam hubungan Islam-Kristen. Penelitian ini akan mengadopsi teori kerangka kerja yang didasarkan dalam pemikiran Francis Fukuyama dan Robert Putnam tentang modal sosial dengan melihat tradisi pela sebagai sebuah modal sosial yang ada di tengah tatanan masyarakat negeri Mamala dan Lateri. Tradisi hubungan pela akan diperkuat dengan adanya tatanan nilai dan norma yang berlaku dalam masyarakat, nilai serta norma tersebut juga merupakan buah dari hal-hal yang terkandung dalam tradisi pela itu sendiri. Hubungan pela yang terbentuk antar kedua negeri ini memunculkan rasa kepercayaan yang tinggi antar kelompok masyarakat yang dibingkai oleh tradisi pela ini sehingga semakin menguatkan identitas kultural negeri Mamala dan Lateri sebagai modal sosial komunitas lintas agama. Menurut Putnam, modal sosial seumpama jembatan yang dapat menghubungkan komunitas-komunitas yang berbeda ideologi, pandangan dan sebagainya, dan pela sebagai modal sosial mampu menjadi jembatan penghubung komunitas berbeda agama di negeri Mamala dan Lateri juga sebagai penghubung solidaritas sebagai sesama orang Maluku yang dibentuk dalam sebuah hubungan kekerabatan dengan media permainan sepakbola. 


\section{e-ISSN 1412-9418 \\ Humanika Vol. 26 no 22019 Copyright @2019 \\ Available online di http://ejournal.undip.ac.id/index.php/humanika}

\section{Metode Penelitian}

Metode Penelitian yang dipakai dalam penelitian ini adalah penelitian kualitatif. Penelitian kualitatif dapat digunakan apabila ingin melihat dan mengungkapkan suatu keadaan maupun suatu objek dalam konteksnya; menemukan makna (meaning) atau pemahaman yang mendalam tentang suatu masalah yang dihadapi, yang tampil dalam bentuk data kualitatif (Yusuf, 2004). Penelitian kualitatif juga merupakan metode-metode untuk mengeksplorasi dan memahami makna yang oleh sejumlah individu atau sekelompok orang dianggap berasal dari masalah sosial atau kemanusiaan (Creswell, 2016). Penelitian dilakukan di negeri Mamala dan Lateri.

Dalam penelitian ini, ada beberapa teknik dalam mengumpulkan data yakni pertama, teknik wawancara mendalam. Wawancara mendalam merujuk pada tujuan yang mendalam guna mengakomodir tujuan wawancara tersebut. Wawancara mendalam adalah interaksi/pembicaraan yang terjadi antara satu orang pewawancara dengan satu informan (Manzilati, 2017). Informan yang diwawancarai ialah badan saniri negeri (Pemerintahan adat) negeri Mamala, sesepuh adat negeri Mamala dan juga para sesepuh dari negeri Lateri, tokohtokoh agama dari kedua negeri (Kyai, Ustad dan Pendeta) serta beberapa anggota masyarakat dari kedua negeri. Kedua, observasi. Observasi yang akan dilakukan adalah observasi kualitatif dimana peneliti langsung turun ke lapangan untuk mengamati perilaku atau aktivitas individuindividu di lokasi penelitian (Creswell, 2016).

\section{Hasil dan Pembahasan}

\section{Modal Sosial Menurut Francis Fukuyama \& Robert Putnam}

Modal sosial dimaknai sebagai upaya menghimpun semua kekuatan-kekuatan sosial komunitas yang dikonstruksikan oleh individu atau kelompok dengan mengacu pada struktur sosial yang menurut penilaian mereka dapat mencapai tujuan individual atau kelompok secara efisien dan efektif dengan modal-modal lainnya (Lawang, 1986). Konsep modal sosial muncul dari pemikiran bahwa anggota masyarakat tidak mungkin dapat secara individu mengatasi masalah yang dihadapi. Diperlukan adanya kebersamaan dan kerjasama yang baik dari segenap anggota masyarakat yang berkepentingan untuk mengatasi masalah tersebut.

Modal sosial termasuk rasa kemauan baik, rasa bersahabat, saling simpati, serta hubungan sosial dan kerjasama yang erat antara individu dan keluarga yang membentuk suatu kelompok sosial (Hanifan, 1916). Selain itu, modal sosial juga sebagai keseluruhan sumber daya baik yang aktual maupun yang potensial yang terkait dengan kepemilikan jaringan hubungan kelembagaan yang tetap dengan didasarkan pada saling kenal dan saling mengakui (Richardson, 1986). Demikian pula, Francis Fukuyama memahami modal sosial (Social Capital) dengan menggunakan konsep kepercayaan untuk mengukur tingkat modal sosial. la berpendapat modal sosial akan semakin kuat apabila dalam suatu masyarakat berlaku norma saling balas membantu dan kerjasama yang kompak melalui suatu ikatan jaringan hubungan kelembagaan sosial. Fukuyama menganggap kepercayaan itu sangat berkaitan dengan akar budaya, terutama yang berkaitan dengan etika dan moral yang berlaku, karena itu dalam tesisnya mengatakan bahwa tingkat saling percaya dalam suatu masyarakat tidak terlepas dari nilai-nilai budaya yang 
dimiliki masyarakat bersangkutan. (Fukuyama, 1997). Berdasarkan penelitiannya di beberapa Negara di Asia, seperti Cina dan Jepang, fukuyama menemukan bahwa untuk mencapai keberhasilan ekonomi diperlukan adanya organisasi-organisasi ekonomi berskala besar dan korporasi yang demokratis. Namun, menurut pendapatnya kelembagaan itu baru dapat berfungsi dengan baik apabila terdapat cukup perhatian terhadap pentingnya peranan-peranan kebiasaan dalam budaya tradisional. Peraturan, kontrak, rasionalitas ekonomi semata tidak cukup menjamin stabilitas dan kesejahteraan masyarakat secara semata. Diperlukan adanya nilai-nilai resiporitas, tanggung jawab moral, kewajiban terhadap masyarakat dan kepercayaan yang lebih didasarkan pada adat kebiasaan daripada perhitungan rasional. (Fukuyama, 1997).

Unsur-unsur pokok modal sosial itu sendiri yatu; kepercayaan (trust), jaringan dan norma. Kepercayaan yang dimaksudkan dalam konteks ini adalah masyarakat memiliki sikap saling percaya. Sikap saling percaya tersebut merupakan modal bagi masyarakat untuk dapat membangun suatu jaringan sosial dengan prinsip kesukarelaan (Voluntary), kesamaan (equality), kebebasan (freedom), dan keadaban (civility) (Arifin, 2009). Adapun norma merupakan seperangkat aturan yang berlaku dan harus dijalankan secara konsisten oleh masyarakat. Pada sekelompok masyarakat yang memiliki secara bersama normal informal, dimana norma tersebut dijadikan sebagai acuan atau pandangan untuk menjalin kerjasama dan berinteraksi meskipun memiliki berbagai macam perbedaan latar belakang.

Jika merujuk pada penjelasan ini maka itulah yang disebut sebagai kearifan lokal (local wisdom) dalam tradisi hubungan pela yang merupakan ikatan dalam sebuah komunitas masyarakat adat yang berlandaskan norma-norma yang membentuk komunitas tersebut yang dimiliki dan dijalankan secara turun-temurun. Sejalan dengan Fukuyama, Putnam menganggap modal sosial sebagai seperangkat hubungan horizontal antara orang-orang. Maksudnya modal sosial terdiri dari "networks of civil engagements", 3 alasan yang mengikuti pemikirannya tersebut adalah; Pertama, adanya jaringan sosial memungkinkan adanya koordinasi dan komunikasi yang dapat menumbuhkan rasa saling percaya di antara sesame anggota masyarakat. Kedua, kepercayaan memiliki implikasi positif dalam kehidupan bermasyarakat, hal ini dibuktikan dengan suatu kenyataan bagaimana keterkaitan orang-orang yang memiliki rasa saling percaya (mutual trust) dalam suatu jaringan sosial memperkuat norma-norma mengenai keharusan untuk saling membantu. Ketiga, berbagai keberhasilan yang dicapai melalui kerjasama pada waktu sebelumnya dalam jaringan ini akan mendorong bagi keberlangsungan kerjasama pada waktu selanjutnya, modal sosial bahkan lebih jauh dapat menjembatani jurang pemisah antara kelompok-kelompok yang berbeda (Putnam, 1993).

Dalam modal sosial ada dimensi kultural yang kaya dengan nilai-nilai budaya sebagai modal sosial yang memungkinkan terpeliharanya hubungan yang harmonis. Pada nilai-nilai budaya yang dimiliki kelompok masyarakat secara tradisional terdapat keseimbangan antara modal sosial yang mengatur keseimbangan antara modal sosial yang mengatur keharmonisan dan solidaritas hubungan internal sesama anggota kelompok, yang disebut dengan istilah bonding social capital atau modal sosial pengikat dan istilah briding social capital yang dapat dikatakan sebagai modal sosial penghubung (Khrisna, 1999). Berdasarkan penjelasan diatas, 


\section{e-ISSN 1412-9418 \\ Humanika Vol. 26 no 22019 Copyright @2019 \\ Available online di http://ejournal.undip.ac.id/index.php/humanika}

penulis menyimpulkan bahwa modal sosial adalah yang mengikat suatu komunitas masyarakat, modal sosial yang lemah menggambarkan kualitas hubungan masyarakat yang lemah pula. Dalam lingkup suatu komunitas tidak terlepas dari norma-norma dan nilai yang memperkuat modal sosial yang ada dalam komunitas tersebut dan tidak menutup kemungkinan modal sosial tersebut yang membentuk perilaku, moral dan etika suatu masyarakat dan menjadi harta yang terkandung dalam masyarakat tersebut, modal sosial tersebut yang mengikat masyarakat tersebut secara internal bahkan juga menjadi jembatan penghubung untuk hubungan eksternal dengan komunitas yang berbeda ataupun hubungan internal dalam masyarakat tersebut yang tidak terlepas dari perbedaan-perbedaan yang ada.

\section{Tradisi Hubungan Pela Bola Sebagai Modal Sosial bagi Negeri Mamala Amalatu dan Lateri}

Seperti yang ditemukan dalam konteks orang Maluku, pela adalah ikatan persahabatan atau persaudaraan yang dilembagakan antara seluruh penduduk pribumi dari dua desa atau lebih. Ikatan tersebut telah ditetapkan oleh para leluhur dalam keadaan yang khusus dan menyertakan hak-hak serta kewajiban-kewajiban tertentu bagi pihak-pihak yang ada di dalamnya (Cooley, 1987). Hubungan kekerabatan pela yang terbentuk di Maluku antara lain dibagi dalam skala primer dan sekunder antara lain; Pela Tuni atau Pela Keras dengan kategori sekunder Pela tumpah darah dan Pela batu karang. Berikutnya Pela tempat sirih dan terakhir Pela-Gandong (Tutupary, 1895). Dijelaskan bahwa pela tampa sirih (tempat sirih) karena ikatan pela dibuat dengan mengedarkan sirih pinang kepada semua yang hadir, Pela Darah karena Pela tersebut dimeteraikan dengan darah dan, Pela batu karang yakni karena ikatan Pela dibuat setelah kapitan (panglima perang) dari kedua negeri yang berperang tidak mampu saling mengalahkan setelah bertaruh di atas batu karang (Hehanussa, 2009).

Dalam tradisi pela perbedaan bukanlah hal yang menjadi problema konflik, sebab justru perbedaan itu telah melebur dalam sebuah konsep janji dan sumpah sebagai "orang basudara (orang bersaudara)" (Ralahallo, 2009). Hubungan pela merupakan hubungan yang sakral, dasardasar sakralitas dari pela diletakkan oleh leluhur ketika dilakukan upacara "sumpah pela" pada saat dibentuknya ikatan pela (Thomas, 2010). Pela menjadi suatu kekuatan bagi identitas masyarakat Maluku, suatu hubungan kekerabatan yang melampaui batas agama yang berbeda. Identitas-identitas inilah yang mengikat Maluku sebagai kesatuan meskipun terbentuk dari latar belakang agama yang berbeda dan cara kehidupan yang berbeda pula tetapi diikat dalam suatu ikatan pela. Secara langsung dapat dikatakan bahwa tradisi hubungan pela merupakan modal sosial yang kuat yang bersumber pada nilai dan kearifan lokal yang mengakomodasi kepentingan bersama, kebiasaan dan tradisi, sehingga potensi dari modal sosial tersebut adalah nilai dan norma yang terkandung serta menjadi wadah untuk mengatur sebuah komunitas masyarakat, ada lembaga atau institusi yang berkontribusi untuk memberikan layanan untuk kepentingan kolektif dan ada tokoh-tokoh masyarakat yang terpercaya dan dipercaya di komunitas tersebut (Abdullah, 2013).

Di Maluku, pela merupakan hubungan yang diwadahkan oleh lembaga-lembaga adat yang berfungsi sebagai pengayom kehidupan komunitas yang berpela, lembaga adat sebagai 
kontrol sosial yang akan melaksanakan ritual-ritual yang telah dikukuhkan dalam tradisi hubungan pela dan didalamnya terdapat semua unsur-unsur tokoh masyarakat yang sangat dihargai, dipercaya dan merupakan orang-orang yang sudah dipilih secara bersama untuk mengayomi komunitasnya sekaligus menjaga hubungan-hubungan pela tersebut turuntemurun. Komposisi nilai dan norma dalam hubungan kekerabatan pela begitu kuat, dihormati dan dijadikan sebagai pedoman hidup masyarakatnya. Sehingga tradisi pela merupakan bentuk modal sosial karena mempunyai kekuatan mengikat suatu komunitas bahkan menjembatani seluruh perbedaan-perbedaan yang ada antar komunitas, sehingga melahirkan koneksi atau jaringan yang kuat untuk melanggengkan suatu masyarakat.

Pela merupakan sebuah relasi dialogis secara horizontal dibangun atas semangat untuk menghidupkan lagi nilai-nilai harmoni dan sebagai cara ampuh penyelesaian konflik yang terjadi ataupun menghalangi konflik-konflik eksternal. Dalam Tradisi hubungan pela, masyarakat yang ber-pela harus melakukan sumpah adat yang menyatakan bahwa mereka sedarah. Konflik ini bisa terjadi antara Islam dengan Islam, Kristen dengan Kristen maupun Islam dengan Kristen (Longgina, 2018). Pela adalah sejarah hidup orang Maluku yang didalamnya terkandung penghayatan akan nilai-nilai relasi antar umat manusia, baik yang diawali dengan atau tanpa ketegangan dan pela adalah penciptaan relasi yang bersifat komunal dan bukan personal (Hehanussa, 2009). Sehingga Tradisi ini telah menjadi identitas khas yang sangat kental dengan nilai-nilai toleransi, integrasi, rekonsiliasi, dan solidaritas yang hadir di bumi Maluku. Pela mempunyai fungsi dan peran terhadap kelangsungan hidup tatanan persaudaraan yang menjadi satu kesatuan dalam masyarakat Maluku, bahka kekuatan hubungan pela sebagai modal sosial yang kuat dapat menjadi pelumas untuk yang memperlancar hubungan dan kerjasama sehingga harapan-harapan individu dapat dapat tercapai secara efisien dan efektif (Abdullah, 2013).

Masyarakat yang ber-pela mempunyai cita-cita dan tujuan hidup yang selaras antara lain untuk tetap mempertahankan identitas kultural dan juga memperkuat rasa persaudaraan dan solidaritas diantara mereka, sehingga modal sosial yang digunakan yakni pela dengan setiap norma dan nilai yang ada akan membantu menyelaraskan itu. Dilihat bahwa hubungan ini menembus batas-batas agama bahkan meleburkannya menjadi hubungan yang murni dengan komposisi nilai-nilai solidaritas dan toleransi sebagai orang Maluku. Modal sosial jembatan (bridging social capital) menjelaskan bahwa segala perbedaan-perbedaan yang ada dalam suatu komunitas masyarakat akan dihubungkan dalam modal sosial jembatan tersebut, menjad penghubung dan pada akhirnya menjadi pengikat yang kuat.

Pela bola negeri Mamala Amalatu dan Lateri dianggap menjadi modal sosial untuk mengikat komunitas Islam-Kristen ini, Mamala yang bermayoritas Muslim dan Lateri yang bermayoritas Kristen. Modal sosial pela menjembatani seluruh perbedaan agama yang ada, dengan latarbelakang yang berbeda tetapi diikat menjadi suatu komunitas ber-pela, dengan cara yang unik melalui media sepakbola. Menarik juga dalam simbol-simbol yang dipakai untuk mengikat hubungan kekerabatan pela Bola kedua negeri ini, yaitu ada 3 simbol yang dipakai untuk mengukuhkan ikatan tersebut yaitu buah durian, sagu lempeng dan ketupat yang mempunyai nilai pengikat hubungan ini. Buah durian yang dibelah menjadi dua bagian 
merupakan simbol penerimaan gelar sebagai saudara pela (Ade-Kaka), serta sebagai simbol saling memiliki bagi kedua negeri. Buah durian dipilih sebagai simbol yakni karena buah durian merupakan komoditi utama di negeri Mamala yang sangat terkenal. Serta kedua simbol lain yang sangat penting adalah sagu lempeng dan ketupat. Sagu lempeng mencirikan makanan lokal orang Maluku tetapi juga sebagai simbol Kekristenan dari masyarakat Lateri, sedangkan ketupat merupakan simbol dari masyarakat muslim Mamala. Dapat dilihat bahwa bahwa masyarakat Negeri Mamala dan Lateri begitu menghargai perbedaan dan menjunjung tinggi toleransi, dibuktikan dengan simbol-simbol yang dipakai. Kedua tidak memaksakan untuk memakai satu simbol yang mewakili keduanya, tetapi memilih sagu dan ketupat sebagai sebuah bentuk rasa menghargai di tengah perbedaan. Tidak ada rasa pemaksaan tetapi mengkolaborasikan menjadi simbol-simbol yang mewakili keduanya.

Pela bola yang dibangun di kedua negeri berbeda agama ini tidak hanya sampai kepada rasa penerimaan dan saling memiliki sebagai saudara semata tetapi hubungan kekerabatan ini menghasilkan janji untuk saling membangun kedua negeri dalam hal apapun, baik itu pembangunan fisik Negeri maupun saling membangun dalam bidang ekonomi, sosial dan masyarakat. Pada akhirnya, proses kerja kolaborasi modal sosial menjadi energi dan kekuatan komunitas, disandarkan pada sifat dan substansi yang dimilikinya yang dibangun diatas nilai kepercayaan, norma dan jaringan yang tidak bisa dipisahkan satu sama lain. Hasil daripada kolaborasi modal sosial memunculkan energi positif, seperti rasa tanggung jawab, kepedulian, kejujuran, kerjasama, inklusif, mutual trust, solidaritas, transparansi, perasaan aman dan nyaman bagi komunitas masyarakat. Sehingga beberapa contoh dari energi positif itu terlihat dalam hal pembangunan rumah ibadat dari kedua negeri ini dibangun serupa yakni menara masjid negeri Mamala dibuat sama dengan toreng lonceng gereja dari negeri Lateri yang menjadi monumen yang menggambarkan pengukuhan hubungan kekerabatan dari kedua negeri. Sehingga proses saling membantu dan membangun tetap dijalankan baik dalam hal renovasi masjid maupun gereja. Monumen kembar ini merupakan wujud simbol yang memiliki nilai budaya yang sangat tinggi, sebagai sebuah sarana untuk mengkomunikasikan tradisi dan sebagai landasan pemahaman bersama. (Dillitson, 2002). Tanda atau simbol memainkan peran sentral dalam kehidupan masyarakat yang berorientasi lisan karena masyarakat memandang simbol sebagai sarana komunikasi. Tempat-tempat suci adalah untuk mengingat masa lalu, menyediakan energi komunal untuk hidup di masa kini dan mengantisipasi masa depan. Gereja dan Masjid di Maluku menyoroti bagaimana kekristenan dan Islam yang saling terkait berada di tempat pemujaan keagamaan, berakar pada memori kolektif jaringan budaya yakni pela sehingga dapat dikatakan Gereja dan Masjid komunitas di Maluku memiliki aspek antaragama dan budaya. Selain itu yang terpenting adalah untuk tetap mengingat hubungan kekerabatan pela sebagai sebuah pedoman hidup bersama yang menyatukan masyarakat. (Lattu, 2019)

Kesakralan dari hubungan kekerabatan pela bola ini juga sangat kental dan sangat dijunjung serta dihormati oleh masyarakat dari kedua negeri hingga sekarang, ada banyak janjijanji dan sumpah-sumpah adat dalam mengikat hubungan pela negeri Mamala Amalatu dan Lateri. Janji yang harus tetap dijaga oleh kedua negeri yakni tidak boleh saling mengawini satu sama lain dan juga ketika diadakannya ritual pesta Pela-Gandong yang selalu bertempat di 
negeri Mamala maka kedua negeri harus menyelesaikan acara tersebut hingga selesai dan tidak boleh melanggar peraturan-peraturan yang telah dirumuskan bersama ketika dulu. Jika terjadi pelanggaran akan setiap janji-janji yang diikat itu makan akan dikenakan sumpah adat. Umumnya dikatakan bahwa pantangan-pantangan itu dipatuhi secara mutlak, terdapat dua jenis sanksi adat yang dikenakan oleh para penguasa desa dan oleh "mereka yang tak kelihatan" sanksi dari penguasa desa merupakan hal yang wajib dilakukan dan pantang untuk menghindar, karena akan mendatangkan sanksi dari para arwah leluhur berupa kemandulan, penyakit dan kematian (Cooley, 1987)

Untuk diketahui juga dalam hampir setiap pela terdapat sanksi-sanksi yang akan dikenakan atau dilimpahkan kepada yang melanggar. Modal sosial meliputi kewajiban dan ekspetasi, potensi informasi, norma dan sanksi efektif, relasi dan wewenang, seperti yang dijelaskan James Wilson tentang kejahatan dan modal sosial, bahwa kekerasan dan kejahatan bukan hanya merugikan individu melainkan secara ekstrem menghambat pembentukan dan pemeliharaan masyarakat, kejahatan mengacaukan ikatan-ikatan yang halus, baik formal maupun informal, kejahatan memecah belah masyarakat, kekerasan dan kejahatan ini akan secara langsung melemahkan modal sosial dan bahkan masyarakat (Abdullah, 2013). Menurut hemat penulis, pelanggaran-pelanggaran terhadap sumpah pela tersebut digambarkan sebagai kejahatan dalam modal sosial yang dapat merusak tatanan masyarakat sekaligus melemahkan esensi dari kekuatan hubungan pela tersebut yang telah diatur oleh nilai dan norma sekaligus sebagai pedoman dalam bertindak dalam komunitas. Dan sanksi-sanksi ada yang diberikan merupakan bentuk dari dimensi modal sosial ketika melanggar setiap norma-norma yang berlaku dalam masyarakat yang mempunyai hubungan pela.

\section{Sepakbola Sebagai Media Terbentuknya 'Pela' Negeri Mamala dan Lateri}

Sepakbola dalam zaman sekarang ini bisa dilihat sangat mendunia bahkan sepakbola telah menjadi seperti sejarah dalam peradaban kehidupan manusia yang didalamnya menciptakan relasi-relasi yang semula tidak dibayangkan sebelumnya dan mempersatukan individu-individu dari berbagai kalangan yang sama sekali berbeda dalam hal suku, ras, bahasa, agama dan bangsa bahkan mencapai ideologi dan Negara. Hubungan pela negeri Mamala dan Lateri dibentuk dan diikat oleh sepakbola sebagai media untuk mengikat kedua negeri yang berbeda agama. Integrasi yang terjadi melalui media permainan sepakbola bagi kedua negeri yang menjalin relasi ini bukanlah sesuatu yang terjadi begitu saja tetapi melalui proses-proses persetujuan yang mendatangkan kesepakatan untuk membangun suatu hubungan kekerabatan dari kedua negeri ini. Sejarah terbentuknya hubungan kekerabatan pela negeri Mamala dan Lateri ini memanglah sangat unik dan anti-mainstream seperti yang telah dijelaskan sebelumnya bahwa hubungan kekerabatan yang dibangun terbentuk dari sebuah media yakni "Sepakbola" memang bagi khalayak umum dipandang sebatas salah satu cabang olahraga, tetapi faktanya sepakbola memberikan kontribusi positif dalam membentuk suatu identitas kultural baru lintas agama bagi negeri Mamala Amalatu dan Lateri. Sepakbola menjadi jembatan dalam membangun ikatan persaudaraan, melanggengkan hubungan kedua negeri dengan mayoritas agama yang berbeda yang probabilitasnya dapat menimbulkan gesekan- 
gesekan atau konflik tetapi sebaliknya harmonisasi terbangun dalam pelbagai perbedaan yang ada.

Atas dasar kesamaan kolektif tersebut itulah Fukuyama menyebutnya sebagai modal sosial, atau menurut Putnam disebut sebagai "stok kepercayaan sosial". Melalui media sepakbola ini, komunitas membentuk suatu ikatan kultural baru yakni pela yang akhirnya menjadi modal sosial, sehingga modal sosial itulah yang menjadi pengikat sekaligus perekat yang memperkuat kohesi sosial dalam suatu masyarakat (Malik, 2007). Dalam narasi terbentuknya pela bola menurut Badan Saniri (pemerintahan adat) negeri Mamala, diceritakan bahwa kedua negeri mengikat hubungan kekerabatan ini karena adanya peristiwa yakni ketika tim kesebelasan negeri Mamala yang tengah bertanding melawan kesebelasan negeri Tulehu pada acara "Pesta Kampung", yang berlangsung di negeri Mamala. Pada saat yang sama beberapa orang dari negeri Lateri sedang membuat pancang-pancang untuk menangkap ikan di sekitar pantai negeri Mamala. Saat pertandingan tersebut salah satu dari pemain negeri Mamala mengalami cidera yang berat dan harus dikeluarkan dari lapangan dan inilah peristiwa yang merupakan cikal bakal terjadinya ikatan pela bola tersebut yakni ketika salah seorang dari negeri Lateri menawarkan diri untuk membantu tim kesebelasan dari negeri Mamala dan kemudian pertandingan kembali dijalankan dengan hasil akhir dari pertolongan itu yakni tim kesebelasan negeri Mamala meraih kemenangan.

Dari momen saling membantu yang terjadi maka raja negeri Mamala meminta kesediaan dari masyarakat negeri Lateri untuk mengizinkan tim kesebelasannya membantu tim kesebelasan dari negeri Mamala, permintaan itu disambut baik oleh raja negeri Lateri dan kemudian disetujui pun oleh tim kesebelasan dari negeri Lateri. Selama satu minggu terjadi perjumpaan terbangunlah hubungan yang begitu erat antar kedua kesebelasan itu, perasaan saling memiliki yang dibangun membuat perbedaan agama kemudian hilang dan diganti oleh perasaan seperti saudara kandung. Ketika telah berakhir seluruh rangkaian perjumpaan tersebut, kedua tim kesebelasan itu hanyut akan rasa haru terutama raja negeri Mamala yang menyaksikan langsung hal tersebut, karena rasa saling memiliki sebagai saudara tidak bisa dibendung lagi maka raja Mamala meminta raja negeri Lateri untuk berkunjung ke negeri Mamala bersama dengan seluruh masyarakat negeri Lateri.

Perjumpaan kembali terjadi sebagai peristiwa yang menjadi sejarah pembentukan identitas lokal tersebut, disaksikan oleh masyarakat dari kedua negeri ini raja negeri Mamala dan raja negeri Lateri mengikat serta mengikrarkan janji untuk menjadi saudara (Ade-Kaka) dalam susah maupun duka dan berjanji untuk saling membangun dan melengkapi satu sama lain walaupun ditengarai oleh perbedaan agama. Peristiwa pengukuhan hubungan pela tersebut membuat segala perbedaan melebur menjadi satu kesatuan yang hakiki, tidak ada lagi sensivitas agama sehingga penyatuan dari kedua negeri ini terjadi. Dapat dilihat bahwa sepakbola sebagai bagian mendasar dari sebuah pembentukan identitas baru, dalam hal ini pembentukan identitas lokal yakni pela, Jarvie dalam tulisannya mengungkapkan bahwa olahraga sebenarnya harus dipahami bukan sebatas olahraga semata tetapi dapat dilihat dalam kacamata dunia sosiologi yang memainkan perannya dalam segi kehidupan masyarakat dan tidak bisa dilepaskan, olahraga dapat menerangi dalam pembuatan identitas dan membangun 
nasionalisme. Pengertiannya adalah bahwa sepakbola yang dilihat dalam ranah olahraga telah mendatangkan perubahan sosial dalam suatu komunitas yang sebelumnya tidak dibayangkan, menciptakan relasi-relasi yang kontuinitas bagi komunitas-komunitas yang berbeda dalam banyak segi, dan memberi makna baru bahwa esensi dari permainan sepakbola ternyata lebih dari sekedar olahraga semata tetapi menjadi kekuatan positif untuk mengubah masyarakat. Bahkan sepakbola melampaui batas-batas yang ada bahkan identitas-identitas serta menjadi pencipta identitas sosial bagi suatu komunitas.

Bagi Jarvie, olahraga dapat berkontribusi pada berbagai bentuk identitas budaya, paham ini sempat dikritik karena akan menjadi akar bagi rasisme dan sebagainya tetapi disini mau menekankan bahwa olahraga membantu untuk merangkai suatu identitas untuk menyatukan segala kepelbagaian yang ada (Jarvie, 2006). Faktanya bahwa sepakbola sebagai sesuatu yang membudaya di era milinieal ini dapat menjadi pengikat yang meretas sekat-sekat perbedaan yang ada termasuk agama bahkan kenyataan yang terjadi sepakbola telah menyatukan dan membangun hubungan kekerabatan negeri Mamala Amalatu dan Lateri. Clifford Geertz dalam pandangannya juga mengenai budaya yang kemudian memperkuat jaring-jaring sosial (Web of Significance) (Geertz, 2002). Jaring-jaring terbentuk melalui sepakbola sebagai representasi simbolik dimana untuk menghasilkan dan mempertahankan makna, dalam pengertian bahwa sepakbola sebagai bentuk simbolik dalam membentuk kebudayaan dengan menghasilkan sebuah relasi baru antar komunitas termasuk hubungan kekerabatan pela negeri Mamala Amalatu dan negeri Lateri.

Sepakbola sebagai pengikat kedua negeri ini juga dilihat sebagai sebuah "situs memori" atau memori kolektif dimana negeri Mamala Amalatu dan Lateri tetap mengingat akan peristiwa-peristiwa yang membuat relasi-relasi mereka terbentuk dan kemudian disahkan sebagai sebuah identitas lokal, yakni pela bola. Memang terlihat sederhana bagi komunitas yang lain, tetapi memori-memori kolektif ini merupakan basis untuk mengingat narasi pela yang diangkat oleh kedua negeri. Pierre Nora dalam studinya mengenai memori dan sejarah mengungkapkan bahwa sisa-sisa pengalaman masih hidup dalam kehangatan tradisi, dalam keheningan adat, dalam pengulangan leluhur, memori mengkristalkan dan mensekresi dirinya sendiri yang terjadi dalam momen-momen historis tertentu, perwujudan memori di situs-situs tertentu dimana rasa kontinuitas tetap ada (Nora, 1989). Dalam pengertian ini, memori akan peristiwa "sepakbola" terus terbekukan dalam hubungan pela yang senantiasa dijaga dan dilestarikan bagi kedua negeri, memori kolektif ini seperti berinkarnasi dari generasi ke generasi untuk tetap membangun identitas lokal yang ada. Sepakbola menjadi semacam ruang sosial (social space) untuk menyelam kedalam relasi-relasi sosial yang ada di negeri Mamala Amalatu dan Lateri, sepakbola sebagai ruang sosial yang mempertemukan kedua negeri berbeda agama menuju harmonisasi, sebagai pencipta identitas lokal dan sebagai memori kolektif yang mengawetkan hubungan kekerabatan pela bola yang dibangun.

\section{'Pela' bola Sebagai Salah Satu Bentuk 'Pela' Modern di Maluku}

Pela bola yang mengikat kedua negeri ini yakni Mamala dan Lateri terjadi pada tahun 1957, dibandingkan dengan sejarah lahirnya pela yang ada di negeri-negeri Maluku yakni sekitar 
tahun 1625 dalam masa Hongitochten dan pada masa perlawanan terhadap penjajahan Belanda. Pela bola negeri Mamala Amalatu dan Lateri hadir pada abad ke-20 sebagai salah satu bentuk pela modern, tradisi hubungan pela ini dari pendekatan Durkheim tentang integrasi sosial maka, integrasi yang didasarkan pada nilai dan normatif berlangsung dalam arena sepakbola yang menciptakan sebuah rasa untuk saling mengikat hubungan bersama yang didasari pada pengalaman kolektif untuk tetap mempertahankan solidaritas tersebut tetap ada atau dapat dikatakan bahwa ikatan tradisi hubungan pela tidak hanya muncul dari masa lampau dilatarbelakangi oleh perjanjian para leluhur semata yang disertai dengan peristiwa-peristiwa perang atau kejadian-kejadian yang mengharuskan untuk mengikat hubungan pela.

Misalnya dalam "Pela Keras" berlatarbelakang sejarah tentang hal-hal yang menyebabkan ditetapkannya pela tersebut, banyak diantara peristiwa itu terjadi ketika orang Maluku baru saja memulai mengadakan hubungan dengan dunia luar di abad ke-15, ketika kesultanan jailolo bersaing untuk meluaskan daerah ke selatan, mencaplok rakyat dan tanah di daerah sekitar seram. Tekanan-tekanan yang dihadapi masyarakat pribumi setelah kedatangan Portugis dan Belanda menimbulkan banyak kebingungan dan kekacauan, ketidakstabilan dan perpindahan pemukiman sehingga dituntut untuk menyerang dan juga diserang dalam keadaan seperti itu bisa saja terjadi bahwa dua kelompok atau lebih mengadakan ikatan di antara mereka dengan sumpah "persaudaraan darah" (Cooley, 1897). Mayoritas masyarakat Maluku cenderung menganggap bahwa relasi atau hubungan kekerabatan yang dibangun dalam ikatan pela di Maluku hanya berdasarkan ikatan-ikatan atau janji-janji yang dinarasikan oleh para pendahulu. Tetapi pela bola hadir sebagai bentuk baru dari hubungan berasaskan kearifan lokal dengan dimediasi oleh budaya pop yang mendunia yakni permainan sepakbola. Maka bisa dilihat pela bola menjadi formasi identitas baru yang tidak hanya terbentuk dari memorimemori peristiwa para leluhur tetapi sebagai bentuk diplomasi setiap hari (Everyday Diplomacy), yakni bahwa diplomasi sehari-hari merupakan cara untuk memperhatikan cara individu maupun masyarakat terlibat dengan dan mempengaruhi keputusan tentang dunia mereka (Marsden, 2006), pela bola merupakan sebuah diplomasi sehari-hari yang diputuskan oleh kedua negeri untuk saling mengikat diri dalam sebuah hubungan kekerabatan. Walaupun merupakan sebuah bentuk dari tradisi hubungan pela modern tetapi fungsi dan peran sosial dari tradisi pela bola tetaplah kuat yakni mendukung dan memvalidasi tatanan sosial, berfungsi sebagai sarana penata kehidupan, seperti yang dijelaskan sebagai modal sosial yang sangat kuat untuk mempererat komunitas masyarakatnya. Dalam bingkai ini pela bola dicerminkan sebagai penanda identitas kolektif kedua negeri. Pela bola sebagai bentuk pela Modern memperlihatkan bahwa modal sosial pela sebagai Bonding Sosial menaruhkan perhatian pada upaya menjaga nilai-nilai yang turun-temurun telah diakui dan dijalankan sebagai bagian dari sebuah tata perilaku (code of conduct) dan perilaku moral (code of ethic). Bonding Sosial kapital dikenal pula sebagai ciri dari sacred society, setiap individu-individu yang merasa berada dalam ikatan hubungan pela ini akan memiliki rasa kewajiban moral yang tinggi untuk saling membantu, menolong bahkan saling memberi dan menerima. (Fukuyama, 1997).

Pela kedua Negeri ini yang dimediasi oleh permainan sepakbola yang terjadi pada tahun 1957 dan masih terbilang baru sebagai salah satu komposisi dalam esensi hubungan berpela 
yang ada di Maluku tidak serta-merta mengurangi sakralitasnya sebagai sebuah tradisi turuntemurun dan tetap menjadi pedoman hidup yang senantiasa dijaga esensi kesakralannya mulai dari awal diikatnya hubungan ini hingga sekarang. Untuk mengingat kembali memori-memori kolektif dari tradisi hubungan pela bola ini, maka dalam 2 tahun sekali yang akan diadakan di kedua negeri, ataupun akan diadakan bertepatan dengan upacara pelantikan raja negeri Mamala, yang merupakan agenda wajib yang didalamnya berkumpul empat negeri yang saling ber-pela yakni Mamala, Lateri, Kaibobu dan Tiouw dan diiringi dengan ritual "Pukul Sapu" yang sudah sangat terkenal. Tidak berhenti sebagai narasi saja tetapi pela bola tetap menjadi sebuah hubungan kekerabatan yang dijaga dan dilakoni oleh komunitas negeri Mamala dan Lateri, hal tersebut sangat tampak ketika ritual panas pela yang terjadi antar kedua negeri yang biasanya diadakan di negeri Mamala, orang-orang Kristen dari Lateri begitu menghargai dan menghormati orang-orang Muslim dari Mamala dengan tidak mengkonsumsi daging babi ketika acara makan patita. Sebaliknya, ketika berlangsungnya hari-hari besar keagaaman seperti natal maka saudara pela yang Muslim akan turut bersama-sama diundang untuk ikut merayakan baik secara eksternal ataupun internal.

Proses ritual "panas pela" merupakan sebuah ritual yang didasari atas perjanjian yang dianggap sakral karena tidak dapat diubah lagi, ritual ini sebagai media untuk mempertegas komitmen atas kehidupan bersama dan memperkenalkan tradisi ini turun-temurun dari generasi ke generasi. Penghargaan serta penghormatan terhadap sesama anggota pela sangat kuat dipegang sebagai sebuah tradisi yang menyatukan. Pela bola sebagai salah satu bentuk hubungan pela modern tetap mempertahankan eksistensinya ketika terjadi konflik sosial di Maluku (1999), Hal ini dikemukakan dengan tegas oleh salah satu sesepuh adat negeri Mamala dengan mengatakan bahwa:

"Konflik Maluku yang terjadi beberapa tahun silam yang dikemas sebagai konflik Islam dan Kristen tidak akan pernah mengurangi rasa persaudaraan bahkan menodai hubungan pela ini. Kami tidak terpengaruh sedikitpun dengan provokasi apapun yang dilakukan. Bahkan ketika konflik masih panas-panasnya terjadi di kota Ambon, saudara-saudara pela dari Lateri tetap mengunjungi kami di Mamala tanpa ada perasaan takut sedikitipun, kami saling percaya, kami tidak akan saling melukai karena hubungan pela kami. Bahkan kami yang memprakarsai perdamaian antara negeri Hitu dan Passo dengan mengadakan pertandingan bola damai, sehingga saudara-saudara kita yang muslim di negeri Hitu dapat melewati jalan raya negeri Passo dengan suasana aman. Hal kecil tetapi membawa hasil yang besar."

Sebenarnya tidak dapat dipungkiri bahwa di era zaman ini jika kita membandingkan bahwa bagi negeri Mamala dan negeri Lateri sepakbola justru menjadi pengikat komunitas dengan nilai-nilai positif yang ada. Berbanding terbalik dengan kasus-kasus yang terjadi di Indonesia khususnya saat ini bahwa sepakbola dipandang sebagai pemicu konflik bahkan sampai menimbulkan korban, sebagai arena berdarah. Justru melalui penulisan ini ingin menjadi kaca untuk dunia di luar sana bahwa identitas-identitas lokal yang langgeng dalam hal ini pela yang merupakan relasi-relasi yang harmonis dalam membentuk dan menjaga kelangsungan kehidupan komunitas di negeri Mamala dan Lateri terwujud dari permainan 
sepakbola. Integrasi yang terjadi adalah karena sesuatu yang tidak pernah dibayangkan yakni dalam sepakbola yang menyatukan segala perbedaan yakni agama. Resistensi-resistensi yang diciptakan dari sepakbola sekiranya membawa kepada terbentuknya hubungan-hubungan positif bahkan pembentukan identitas-identitas lokal yang membawa kepada nilai-nilai toleransi dan solidaritas bukan sebagai alat untuk disintegrasi tetapi sebagai arena integrasi sosial kemasyarakatan. Pela bola negeri Mamala dan Lateri menjadi kacamata baru bagi masyarakat luas bahwa sepakbola yang yang tidak ada sangkut pautnya dengan adat istiadat yang kental tetapi bisa menjadi a solidarity making dalam mengintegrasikan masyarakat selain sebagai pembentuk identitas lokal melalui memori-memori kolektif yang menyatukan kedua negeri ini. Sehingga dapat dikatakan bahwa sepakbola semacam ritual sosial dan menjadi alat politik integrasi bagi masyarakat Maluku dalam membangun hubungan pela yang tidak hanya didasari dari perjanjian leluhur di masa lalu dan bentuk ini memberikan harapan bahwa segala sesuatu peristiwa yang terjadi di masa kini, dapat membuat masyarakat menyatu dalam dimensi apapun, bukan hanya pada hal-hal masa lampau yang mengikat tetapi peristiwaperistiwa yang terjadi masa kini pun masyarakat Maluku bisa mengintegrasikan diri untuk dapat menciptakan sebuah formasi identitas kultural untuk melanggengkan solidaritas lintas agama.

\section{Simpulan}

Tradisi hubungan pela di Maluku merupakan suatu modal sosial yang harus dijaga dan tetap dilestarikan apapun kondisi yang terjadi. Modal sosial tradisi pela secara langsung menguatkan solidaritas dalam masyarakat, memperkuat sendi-sendi kemanusiaan dalam sebuah masyarakat, serta melanggengkan nilai kearifan lokal yang diwariskan oleh leluhur guna menjaga tatanan masyarakat adat untuk semakin memperkuat norma dan moral. Penyatuanpenyatuan dalam menciptakan hubungan pela yang terjadi dalam kehidupan masyarakat terlebih khusus bagi hubungan lintas agama atau hubungan Islam-Kristen yang ada di Maluku dapat saja terjadi melalui sebuah fenomena-fenomena yang terjadi dalam kehidupan sosial masa kini. Salah satu media yang populer adalah sepakbola.

Sepakbola dilihat sebagai sebuah olahraga yang begitu membius para khalayak ramai yang didalamnya menyatukan segala identitas-identitas yang sangat berbeda, sepakbola bukan saja menciptakan relasi-relasi yang hanya dipandang sebagai relasi sosial semata, tetapi menciptakan sebuah relasi budaya yakni sebuah identitas kultural yang begitu sakral nilainya yang begitu dijunjung dan dijaga turun-temurun dalam masyarakat. Pela bola negeri Mamala dan Lateri merupakan sebuah representasi hubungan pela yang bukan hanya didasari atas perjanjian para leluhur di masa lampau terkait dengan peperangan antar negeri dan juga peristiwa-peristiwa mistis tetapi hubungan pela dapat diikat melalui sebuah media permainan olahraga yakni sepakbola. Pela bola yang dibangun dan diikat telah menjadi kekuatan modal sosial yang melahirkan nilai-nilai kepercayaan dan solidaritas untuk tetap mengawetkan hubungan tersebut. Modal sosial tersebut menjadi jembatan dalam menghubungkan segala perbedaan yang ada dalam masyarakat terutama dalam menjaga keharmonisan hubungan lintas agama.

Narasi pela negeri Mamala-Lateri memberi suatu hal yang baru bagi kehidupan budaya lokal dalam masyarakat Maluku sehingga dapat dikatakan pela negeri Mamala dan Lateri 
merupakan bentuk modern dari ikatan hubungan pela di Maluku. Hubungan Islam-kristen yang melatarbelakangi kedua Negeri ini tidak melahirkan sebuah disintegrasi melainkan integrasi yang bersifat normatif, mediasi sepakbola menjadi arena yang sangat penting dalam menciptakan sebuah identitas kultural bagi negeri Mamala dan Lateri. Sepakbola telah menjadi sebuah ruang sosial yang mengutuhkan sebuah identitas kultural yang diwadahi dalam pela bola negeri Mamala dan Lateri. Hubungan kekerabatan tetap dipertahankan melalui segala bentuk ritual-ritual adat dan juga ritual-ritual sosial yang semakin memupuk rasa solidaritas antar kedua negeri sehingga ikatan pela bola tetap menjadi sebuah memori kolektif masyarakat kedua negeri dan kekuatan untuk menjaga relasi persaudaraan antar umat beragama terutama sebagai orang Maluku (Potong di kuku rasa di daging, sagu salempeng dipatah dua, ale rasa beta rasa).

\section{Referensi}

Abdullah, Suparman. 2013. Potensi dan Kekuatan Modal Sosial Dalam Suatu Komunitas. SOCIUS, Vol. XII, hlm. 15-20.

Arifin, Samsul. 2009. Studi Agama: Perspektif Sosiologi dan Isu-isu Kontemporer. Malang: UMM Press.

Attamimy, M. 2014. Pela-Gandong and Harmonization Life of Brotherhood (Orang Basaudara) (Study Case The Relations of Islam and Christianity Post Conflict In Ambon). Al-Ulum IAIN Sultan Amai Gorontalo, Vol.14 (2), hlm. 275-294.

Bayo, Longgina Novadona. et.al. 2018. Rezim Lokal Di Indonesia: Memaknai Ulang Demokrasi Kita. Jakarta: Yayasan Pustaka Obor Indonesia.

Bartels, Dieter. 2017. Di Bawah Naungan Gunung Nunusaku: Muslim-Kristen Hidup Berdampingan di Maluku Tengah. Jakarta: Kepustakaan Populer Gramedia.

Creswell, John W. 2016. Reseacrh Design: Pendekatan Metode Kualitatif, Kuantitatif, dan Campuran. Yogyakarta: Pustaka Pelajar.

Cooley, Frank L. 1987. Mimbar dan Takhta: Hubungan Lembaga-lembaga Keagamaan dan Pemerintahan di Maluku Tengah. Jakarta: Pustaka Sinar Harapan.

Dillitson, F,W. 2002. The Power of Symbols. Yogyakarta: Kanisius.

Fukuyama, Francis. 1997. Social Capital (The Tanner Lectures on Human Values). Oxford: Brasenose College.

Geertz, Clifford. 1992. Tafsir Kebudayaan. Yogyakarta: Kanisius.

Giulianotti, Richard. et.al. 1995. Football, Violence and Social Identity. New York: Routledge.

Handoko, Anung. 2014. Sepakbola Tanpa Batas: City Of Tolerance. Yogyakarta: Kanisius.

Hanifan, Lyda Judson. 1916. The Rural School Community Center. Annals of The American Academy of Political and Sosial Science. hlm. 130-137.

Hehanussa, Jozef M. N. 2009. Pela dan Gandong: Sebuah Model untuk Kehidupan Bersama dalam Konteks Pluralisme Agama di Maluku. Gema Teologi Duta Wacana, Vol.33 (1), hlm.1-15.

Huwae, Sylvia. 1995. Divided Opinions About Adatpela: A Study of Pela Tamilou-SirisoriHutumuri. Cakalele Scholar Space Manoa Hawai, Vol. 5, hlm. 77-92. 
Iwamony, Rachel. 2010. The Reconciliatory Potential Of The Pela In The Mollucas: The Role Of The GPM In This Transformation Process. ter vergkrijging van de graad Doctor aan de Vrije Universiteit Amsterdam.

Jarvie, Grant. 2006. Sport, Culture And Society. New York: Routledge.

Kupper, Simon. 1994. Soccer Against The Enemy. New York: Nation Books.

Kennedy, Eddward S. 2014. Sepak Bola Seribu Tafsir. Yogyakarta: Indie Book Corner.

Krishna, Anirudh, Elizabeth Shrader. 1999. Social Capital Assessment Tool. Conference On Social Capital and Poverty Reduction. hlm. 1-21.

Lattu, Izak Y. M. 2018. Menolak Narasi Tunggal: Diskursus Agama, Pluralisme dan Demokrasi. Salatiga: Satya Wacana University Press.

. 2018. Orality and Interreligious Relationships: The Role of Collective Memory in ChristianMuslim Engagements in Maluku, Indonesia. Ph.D., Diss. The Graduate Theological Union. 2019. Oral Based Interreligious Engagements in Indonesia. Annual Review of The Sociology of Religion; Interreligious Dialogue From Religion to Geopolitics, Vol. 10, hlm. 70-90.

Lawang, Robert M.Z. 1986. Teori Sosiologi Klasik dan Modern Jilid II. Jakarta: Gramedia.

Malik, A MTT. 2007. Pura dan Masjid: Konflik dan Integrasi Pada Suku Tengger Kec. Sumbar Kab. Probolinggo. Jakarta: Balai Penelitian dan Pengembangan Agama Departemen Agama RI.

Manzilati, Asfi. 2017. Metodologi Penelitian Kualitatif: Paradigma, Metode Dan Aplikasi. Malang: Universitas Brawijaya Press.

Marsden, Magnus. et.al. 2016. Everyday Diplomacy: Introduction to Special Issue. The Cambridge Journal of Anthropology 34 (2). hlm. 1-22.

Nora, Pierre. 1989. Between Memory and History: Les Lieux de Memoire. Representations, No.2. hlm. 7-24.

Prastyawan, Erik Bagus. 2018. Stereotip dan Konflik Antar Suporter Sepakbola Persibat dan Persip Pekalongan. Persepsi, Vol.1 (1), hlm. 45-64.

Putnam, Robert. et.al. 1993. Making Democracy Work: Civic Traditions In Modern Italy. Princeton, N.J: Princeton University Press.

Ralahallo, Roubrenda N. 2009. Kultur Damai Berbasis Tradisi Pela Dalam Perspektif Psikologi Sosial. Jurnal Psikologi Universitas Gadjah Mada, Vol.36 (2), hlm. 177-188.

Richardson, J. 1986. Handbook Of Theory And Research For The Sociology Of Education. Westport City: Greenwood Press.

Rumpoko, Satrio Sakti. 2018. Kekerasan dalam Sepakbola. Jurnal Ilmiah Penjas, Vol.4 (3), hlm. 35-52.

Sukmono, Filosa Gita. 2010. Rivalitas Aremania dan Bonekmania. Jurnal LP3I, Vol.8 (2), hlm. 120.

Thomas, Frans. 2010. Wacana Tradisi Pela Dalam Masyarakat Ambon. Bahasa dan Seni, Vol.38 (2), hlm. 166-180.

Tutupary, C. 1895. De Pela-Schap In Centraal-Molluken. Zelfbeschikking 3.

Wattimena, Lucas. 2010. Pela Antara Negeri Latuhalat dan Negeri Alang: Perspektif Antropologi Sosiologi dalam Dinamika Sosial Budaya. Kapata Arkeologi, Vol.6 (10), hlm. 90-100.

Yusuf, A. Muri. 2004. Metode Penelitian: Kuantitatif, Kualitatif dan Penelitian Gabungan. Jakarta: Kencana 